\title{
Nickel, palladium and rhodium induced IFN-gamma and IL- I 0 production as assessed by in vitro ELISpot-analysis in contact dermatitis patients
}

Valentina Bordignon*, Francesca Palamara, Paola Cordiali-Fei, Antonella Vento, Arianna Aiello, Mauro Picardo, Fabrizio Ensoli and Antonio Cristaudo

Address: Laboratory of Clinical Pathology, Department of Allergology and Laboratory of Skin Physiopathology, Institute San Gallicano, IRCCS, IFO, Rome, Italy

Email: Valentina Bordignon* - bordignon@ifo.it; Francesca Palamara - cristaudo@ifo.it; Paola Cordiali-Fei - cordiali-fei@ifo.it; Antonella Vento - cordiali-fei@ifo.it; Arianna Aiello - cordiali-fei@ifo.it; Mauro Picardo - picardo@ifo.it; Fabrizio Ensoli - ensoli@ifo.it; Antonio Cristaudo - cristaudo@ifo.it

* Corresponding author

\section{Published: 15 May 2008}

BMC Immunology 2008, 9:19 doi:10.1 186/147|-2172-9-19
Received: I October 2007

Accepted: 15 May 2008

This article is available from: http://www.biomedcentral.com/I47/-2/72/9//9

(c) 2008 Bordignon et al; licensee BioMed Central Ltd.

This is an Open Access article distributed under the terms of the Creative Commons Attribution License (http://creativecommons.org/licenses/by/2.0), which permits unrestricted use, distribution, and reproduction in any medium, provided the original work is properly cited.

\begin{abstract}
Background: Recent attempts to diminish nickel use in most industrial products have led to an increasing utilization of alternative metal compounds for destinations such as the alloys used in orthopaedics, jewellery and dentistry. The present study was undertaken with the aim to evaluate the potential for an allergic response to nickel, palladium and rhodium on the basis of antigenspecific induction of inflammatory/regulatory cytokines, and to characterize, according to the cytokine profiles, the nature of simultaneous positive patch tests elicited in vivo.

Peripheral blood mononuclear cells (PBMC) from 40 patients with different patch test results were kept in short term cultures in the presence of optimized concentrations of $\mathrm{NiSO}_{4} \times 6 \mathrm{H}_{2} \mathrm{O}, \mathrm{PdCl}_{2}$ and $\mathrm{Rh}\left(\mathrm{CH}_{3} \mathrm{COO}\right)_{2}$. The production of IFN- $\gamma$ and IL- 10 elicited by metal compounds were analyzed by the ELISpot assay.

Results: We found a specific IFN- $\gamma$ response by PBMC upon in vitro stimulation with nickel or palladium in well recognized allergic individuals. All controls with a negative patch test to a metal salt showed an in vitro IL-IO response and not IFN- $\gamma$ production when challenged with the same compound. Interestingly, all subjects with positive patch test to both nickel and palladium (group 3) showed an in vitro response characterized by the release of IFN- $\gamma$ after nickel stimulation and production of IL-10 in response to palladium.

Conclusion: These results strongly suggest that the different cytokine profiles elicited in vitro reflect different immune responses which may lead to the control of the allergic responses or to symptomatic allergic contact dermatitis. The development of sensitive and specific in vitro assays based on the determination of the cytokine profiles in response to contact allergens may have important diagnostic and prognostic implications and may prove extremely useful in complementing the diagnostic limits of traditional patch testing.
\end{abstract}




\section{Background}

Allergic contact dermatitis (ACD) affects a large fraction of the general population being most frequently elicited by nickel (Ni), which is responsible of a delayed-type hypersensitivity clinically revealed by the demonstration of eczematous reactions upon patch testing and by laboratory testing of antigen-specific T-cell proliferation [1-3]. These alterations are the result of the interaction between the metal ions, which act as haptens, and the skin surface, thus favouring the contact and binding with cellular and extracellular matrix proteins [4-6], and the induction of a cellular immune response against the hapten-carrier protein complex $[7,8]$. Recent attempts to diminish $\mathrm{Ni}$ use in most industrial products have led to an increase in the use of different metal compounds for specific destinations such as the alloys used in orthopaedics, jewellery and dentistry [9]. For instance, the use of palladium (Pd) increased in the past 10 years [10] also due to the fact that dentistry alloys containing Pd appear more resistant to mechanical wearing effects $[11,12]$. Similarly, rhodium (Rh), which is primarily used as an alloying agent to harden platinum and Pd, it is now employed in electrical material because of its low electrical and contact resistance, in jewellery (platings of silver or white gold because of its silvery white colour), in optical instruments and dental prostheses.

Nevertheless, it has been recently recognized that also exposure to metal ions such as Pd, chromium, cobalt and gold, can induce a cellular immune response and clinical manifestations of ACD, even if less frequently than $\mathrm{Ni}$ [13-15]. In fact, positive patch testing to $\mathrm{PdCl}_{2}$ and clinical manifestation of ACD to Pd have been described with increasing frequency $[16,17]$. Despite its low sensitization potential, also Rh has been reported as sensitizer in the form of salt [18].

In Ni sensitized subjects a simultaneous patch test reactivity to Pd has been frequently reported $[19,20]$ and a double sensitization can be hypothesised especially in individuals wearing dental prosthesis. Nevertheless, a cutaneous cross-reactivity cannot be excluded for the chemical and structural similarities of $\mathrm{Ni}$ and Pd [21]. Metal ions are incomplete antigens which have to bind to endogenous peptides to be "visible" to the immune system [7] and Ni and Pd encountering the same cellular environment might form in vivo complexes with similar proteins thus eliciting cross-recognizing immune responses [17]. Moreover, two independent in vitro studies demonstrated an immunologic cross reactivity between these metals at the T cell clonal level $[22,23]$.

Identifying both a double sensitization and a lymphocyte cross-reactivity to different metal ions in vivo is an important issue for clinicians in directing the choice of implant materials in order to avoid incompatible reactions. Consequently, the diagnosis of ACD to both Ni and Pd needs in vitro assays complementary to patch testing $[24,25]$. Indeed, the variability of the readouts obtained with patch testing have stimulated a number of studies aimed at developing assays characterizing the immune response to metal salts. Recently, Minang et al. [26] analyzed the different cytokine profiles induced by nickel in allergic or tolerant subjects by enzyme-linked immunospot (ELISpot) assay. In fact, the sensitivity and specificity of the ELISpot assay allow the measurement of very low frequencies of cytokine-producing cell, therefore offering a powerful tool for the detection and characterization of $\mathrm{Ni}$ sensitization with important implications for diagnostic strategies $[27,28]$.

The present study was undertaken with the aim to evaluate the potential of the ELISpot assay in determining sensitivities to $\mathrm{Ni}$ or Pd and to $\mathrm{Ni}$ and $\mathrm{Pd}$ on the basis of specific induction of inflammatory/regulatory cytokines. Since all subjects were skin challenged to $\mathrm{Ni}$, Pd and $\mathrm{Rh}$ salts, and none of them had positive skin reactivity to Rh, this metal was employed to assess the cytokine profile in non allergic subjects and to explore the possibility to identify a cellular immunity against materials with traces of heavy metals.

\section{Results}

\section{Patch tests}

To analyse the cytokine response to metals, we considered four different groups of subjects according to their skin responses. As summarized in Table 1, group 1 included 10 patients with a strong positive reaction to $\mathrm{Ni}$; group 2 included 10 patients with strong $(\mathrm{n}=7)$ or moderate $(\mathrm{n}=$ 3) hypersensitivity to Pd; group 3 included 10 patients showing a strong reactivity to $\mathrm{Ni}$ and a simultaneous weak $(\mathrm{n}=4)$ or moderate $(\mathrm{n}=6)$ response to Pd; and, finally, group 4 included 10 patients with negative patch testing to all metals investigated. All patients enrolled in the study $(\mathrm{n}=40)$ had a negative patch test response to $\mathrm{Rh}$.

\section{IFN- $\gamma$ and IL- 10 production by PBMC in response to $\mathbf{N i}$, Pd and $R h$}

To determine the production of IFN- $\gamma$ and IL-10 upon in vitro stimulation, PBMC from patients with different patch test results were kept in short term cultures in the presence of $\mathrm{NiSO}_{4} \times 6 \mathrm{H}_{2} \mathrm{O}, \mathrm{PdCl}_{2}$ and $\mathrm{Rh}\left(\mathrm{CH}_{3} \mathrm{COO}\right)_{2}$ and analyzed by the ELISpot assay.

IFN- $\gamma$ and IL-10 basal response or elicited by metal salts or PHA in PBMC from different groups of patients are shown in Figure 1. The primary readouts of spot forming cells for each experimental condition in individual patients are also shown in Table 2 . 
Table I: Characteristics of patients and healthy controls.

\begin{tabular}{|c|c|c|c|c|c|}
\hline Group Subject n. & Sex & Age range (median) & Patch test to $\mathrm{Ni}$ & Patch test to Pd & Patch test to $\mathbf{R h}$ \\
\hline \multirow[t]{2}{*}{$1 \mathrm{n}=10$} & $9 \mathrm{~F}$ & $28-40(30)$ & $9+++$ & $9-$ & $9-$ \\
\hline & I M & 30 & $1+++$ & I- & $1-$ \\
\hline \multirow[t]{2}{*}{$2 n=10$} & $9 \mathrm{~F}$ & $28-38(33)$ & $9-$ & $7+++/ 2++$ & $9-$ \\
\hline & I M & 40 & I - & $1++$ & I- \\
\hline \multirow[t]{2}{*}{$3 n=10$} & $9 \mathrm{~F}$ & $29-40(32)$ & $9+++$ & $6++/ 3+$ & $9-$ \\
\hline & $I M$ & 39 & $1+++$ & $1+$ & $1-$ \\
\hline \multirow[t]{2}{*}{$4 n=10$} & $9 \mathrm{~F}$ & $28-38(33)$ & $9-$ & $9-$ & $9-$ \\
\hline & I M & 36 & I- & I- & I- \\
\hline
\end{tabular}

As described in the methods, patch test reactivity to the different metal salts was defined as strong (+++: oedema, erythema, papules and vesicles), moderate (++: oedema, erythema and papules), weak (+: oedema and erythema) or no reaction (-).

PHA stimulated cultures invariably showed increased numbers of IFN- $\gamma$ or IL-10 producing cells with Indexes ranging from 6.8 to 8.3 , and the values did not significantly differ among the different groups, therefore excluding differences in the capability of different subjects to rise a specific cytokine response or impairment of cellular function due to cryopreservation.

Remarkably, IFN- $\gamma$ releasing cells upon metal stimulation were the most represented in strict association with results of the in vivo responses. In fact, IFN- $\gamma-\mathrm{Ni}$ responsive cells (Index $>3$ ) were detected in subjects with positive patch test to Ni either alone (group1) or in association with moderate or weak response to Pd (group 3) $(\mathrm{P}=0.28)$. IFN- $\gamma$-Pd responsive cells were detected only in subjects with strong or moderate Pd positive patch testing (group 2 ), and not in subjects with moderate or weak in vivo response to $\mathrm{Pd}$ associated with a strong $\mathrm{Ni}$ reactivity (group 3) $(\mathrm{P}<0.0001)$.

All subjects with negative patch test results showed an in vitro IL-10 production upon metal stimulation while any positive or ambiguous IFN- $\gamma$ response to $\mathrm{Ni}$, Pd or Rh was present. Interestingly a different in vitro behaviour was found between subjects showing a monosensitization to $\mathrm{Pd}$ and subjects with concomitant skin reactivity to Pd and $\mathrm{Ni}$. In fact, these subjects (group 3 ) had an in vitro reactivity more similar to $\mathrm{Ni}$ monosensitized patients (IFN- $\gamma$-Ni responsive cells: $\mathrm{P}=0.28$; IL-10-Ni responsive cells: $\mathrm{P}=0.19$ ) rather than to Pd monosensitized subjects (IFN- $\gamma$-Ni responsive cells $\mathrm{P}<0.0001$; IL-10-Ni responsive cells: $\mathrm{P}<0.0001)$.

Overall results showed that IL-10 producing cells in response to metals were invariably associated to a lack of IFN- $\gamma$ production. This is well visualized by the scatter plots (Figure 2) of individual Index values obtained in response to $\mathrm{Ni}$ or $\mathrm{Pd}$ in all groups of patients, where it can be appreciated that IFN- $\gamma$ or IL-10 production in response to metal salts are mutually exclusive, while PHA is capable of inducing both cytokines. Statistical analysis confirmed the significant negative correlation between IFN- $\gamma$ and IL10 production $(\mathrm{P}<0.0001)$. The same diagram (Figure 2$)$ reporting the individual responses in the different group of patients also shows that the in vivo moderate and weak reactivity to Pd, observed in association to strong reactivity to $\mathrm{Ni}$ (group 3 ), did not match the in vitro response, that was clearly sustained by IL-10 rather than IFN- $\gamma$ producing cells.

\section{Discussion}

In the present study, we have investigated the profiles of cytokine production by PBMC of ACD patients and healthy controls in response to the well known contact allergens $\mathrm{Ni}$ and $\mathrm{Pd}$, or to $\mathrm{Rh}$, considered to have a low sensitization potential, through the ELISpot assay.

The results showed that PBMC from well recognized allergic individuals affected by ACD have a higher frequency of IFN $-\gamma$ releasing cells upon in vitro stimulation with $\mathrm{Ni}$ or $\mathrm{Pd}$, as compared to control groups. Most interestingly, we found that PBMC from all the individuals exhibiting a negative skin response to a metal salt (group 4) revealed a clear IL-10 response when challenged with the same metal, in the absence of any detectable IFN- $\gamma$ response. Accordingly, all subjects included in the study had a negative skin response to $\mathrm{Rh}$, which was invariably associated to Rh-induced IL-10 production in vitro.

The immunologic mechanisms responsible for the clinical hypersensitivity towards metals have been recently reviewed [7]. It is known that Ni-specific, IFN- $\gamma$-producing $\mathrm{CD} 4^{+}$and $\mathrm{CD} 8^{+} \mathrm{T}$ cells are major effectors of sensitization and directly responsible for skin manifestations $[6,29]$, whereas IL-10 and TGF- $\beta$-secreting regulatory T cells are thought to down-modulate the response $[2,30,31]$. The deleterious expansion of Ni-specific, effector CD8+ T cells might be thus prevented by regulatory mechanisms, including those induced by hapten-specific suppressor $\mathrm{T}$ cells [32]. In humans IL-10 has been identified as a potent anti-inflammatory cytokine produced by both Th1 and Th2 CD4+ T cells [33], which inhibits T cell proliferation 
A

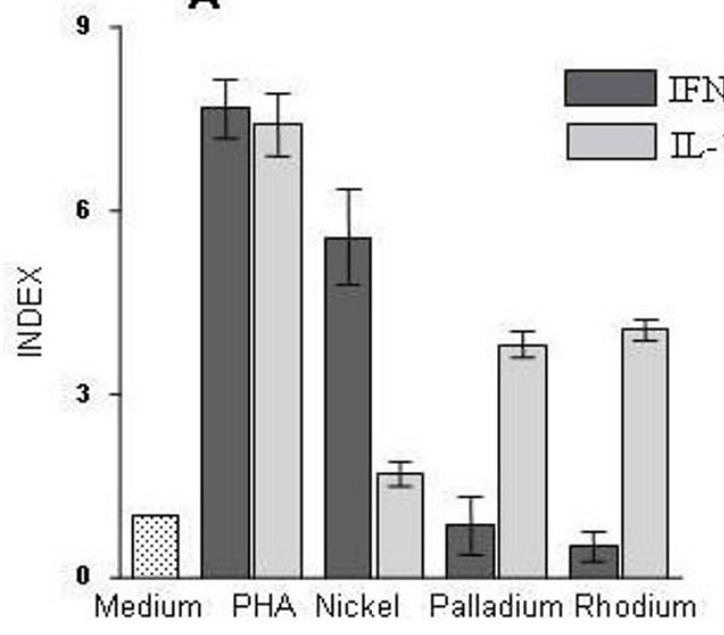

B

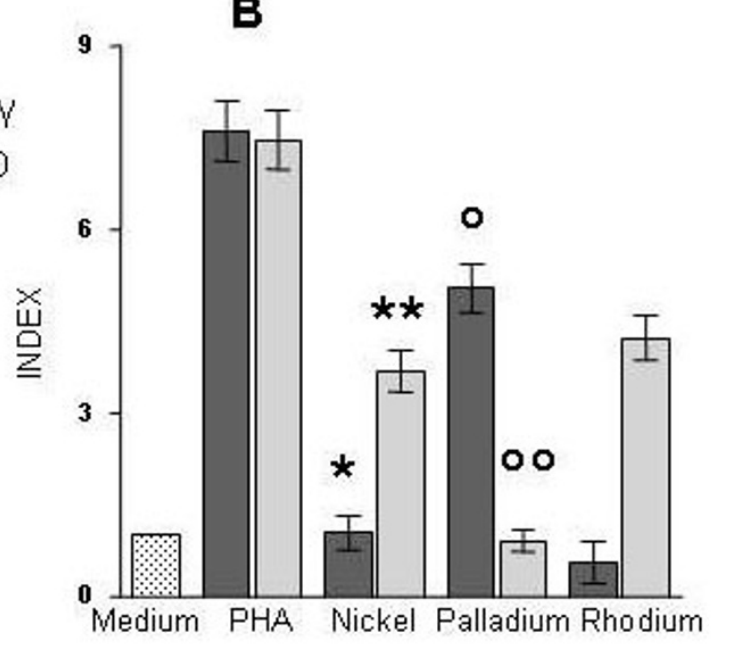

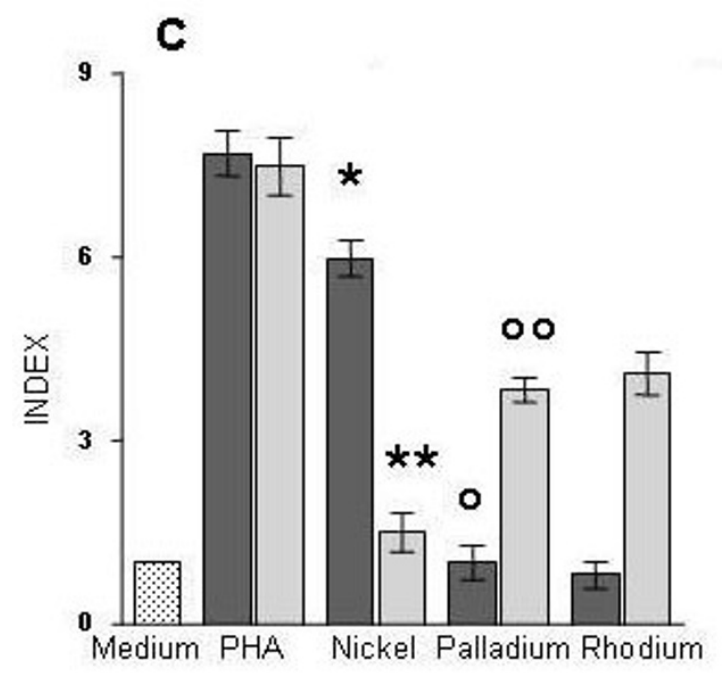

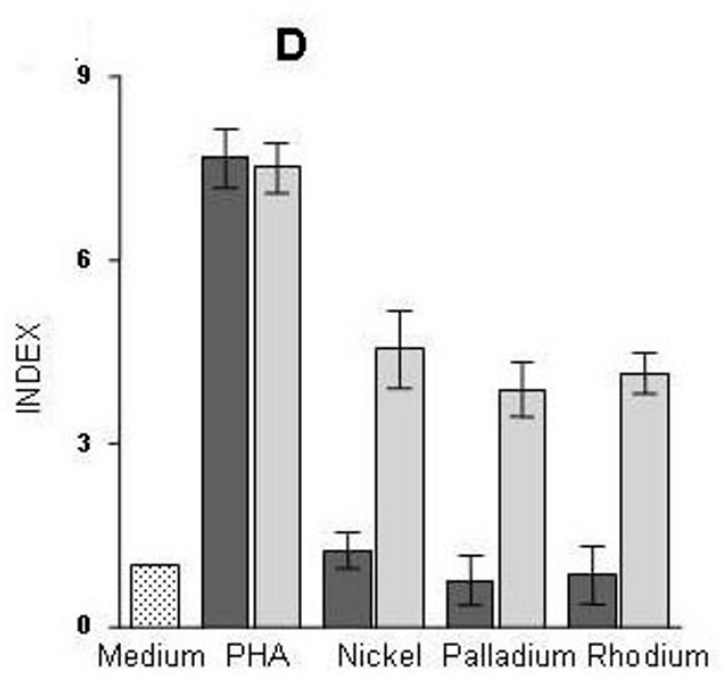

Figure I

Cytokine response elicited by metals or PHA by ELISpot analysis. Elispot results of detection of IFN- $\gamma$ or IL- I0 producing PBMC upon stimulation with $\mathrm{Ni}(20 \mu \mathrm{g} / \mathrm{ml})$, Pd $(2.5 \mu \mathrm{g} / \mathrm{ml})$, Rh $(5 \mu \mathrm{g} / \mathrm{ml})$ or PHA (I $\mu \mathrm{g} / \mathrm{ml})$ were expressed as Index values. Index is expressed by the ratio between the number of spot forming cells (IFN- $\gamma$ and IL-I0 producing PBMC) upon stimulation with metal salts and those present in the absence of stimuli (spontaneous cytokine production). The mean values of Index values \pm SD were obtained for the 4 different groups of 10 subjects according to their in vivo reactivity to metal salts. Cytokine producing cells in control triplicate wells with medium alone was the baseline value $($ Index $=1)$. Panel A: patch test positive to $\mathrm{Ni}$ (group I); B: patch test positive to Pd (group 2); C: patch test positive to Ni and Pd (group 3); D: negative patch test (group 4). The statistical analysis between IFN-g and IL- IO producing cells upon stimulation with $\mathrm{Ni}$ or $\mathrm{Pd}$ between patients belonging to group $C$ and $A$ or $B$ was performed using the Mann-Whitney test. The highly significant differences $(P<$ $0.000 \mathrm{I})$, found between group $\mathrm{C}$ and $\mathrm{B}$, are indicated by symbols $\left(*, * *,{ }^{\circ},{ }^{\circ}\right)$. 
Table 2: Individual values of spot forming cells for each experimental condition expressed as mean values and Standard Errors of triplicate wells.

\begin{tabular}{|c|c|c|c|c|c|c|c|c|c|c|c|c|}
\hline & \multirow[b]{2}{*}{ Subject $n$. } & \multirow[b]{2}{*}{$\begin{array}{l}\text { Mean } \\
\text { Std. Error }\end{array}$} & \multicolumn{5}{|c|}{ IFN- $\gamma$} & \multicolumn{5}{|c|}{ IL-I 0} \\
\hline & & & WIO & PHA & $\mathbf{N i}$ & Pd & $\mathbf{R h}$ & W/O & PHA & $\mathbf{N i}$ & $\mathbf{P d}$ & $\mathbf{R h}$ \\
\hline \multirow{20}{*}{$\begin{array}{c}\text { Patch test positive to } \mathrm{Ni} \\
\text { (Group I) }\end{array}$} & I & Mean & 18,67 & $|5|$ & 116 & 14,33 & 5,667 & 19 & 132 & 36 & 79,67 & 76 \\
\hline & & Std. Error & 2,404 & 4,359 & 3,055 & 1,202 & 0,8819 & 0,5774 & 3,606 & 2,082 & 3,93 & 3,786 \\
\hline & 2 & Mean & 25,17 & 164,3 & 150 & 29,33 & 17,67 & 21 & 157,3 & 36,5 & 73 & 86,33 \\
\hline & & Std. Error & $\mathrm{I}, 74$ & 6,766 & 3,215 & 2,333 & 1,453 & 2,082 & 6,36 & 0,2887 & 2,309 & 2,333 \\
\hline & 3 & Mean & 27,67 & 203 & 136,5 & 19,33 & 16,67 & 11,67 & 92 & 22,5 & 47 & 52 \\
\hline & & Std. Error & 2,333 & 3,606 & 0,866 & 0,8819 & 1,453 & 0,8819 & 3,606 & $\mathrm{I}, 443$ & 3,606 & 2,887 \\
\hline & 4 & Mean & 26,67 & 203 & 168,3 & 18,67 & 5,333 & 33,33 & 270 & 62,67 & 51,33 & 132,7 \\
\hline & & Std. Error & 2,404 & 9,074 & 3,48 & 1,202 & $\mathrm{I}, 202$ & I,202 & 6,351 & 6,333 & 1,667 & 5,207 \\
\hline & 5 & Mean & 30,67 & 246,7 & 168,3 & 27,33 & 27,33 & 38 & 289 & 65,33 & 143,3 & 147,7 \\
\hline & & Std. Error & 0,8819 & 1,856 & 2,603 & 0,8819 & 1,764 & 2,517 & 6,083 & 2,603 & 2,963 & 7,311 \\
\hline & 6 & Mean & 13,33 & 100,3 & 53 & 25 & 6,667 & 22 & 177 & 32,67 & 79,33 & 93,67 \\
\hline & & Std. Error & 2,186 & 3,18 & 3,055 & I,732 & $\mathrm{I}, 202$ & 5,568 & 6,658 & 2,906 & 0,8819 & 4,667 \\
\hline & 7 & Mean & 21,33 & $|7|, 7$ & 119,3 & 10,83 & 10,5 & 21,67 & 147,3 & 35,67 & 85,33 & 91 \\
\hline & & Std. Error & 0,3333 & 3,667 & 4,667 & 0,6009 & 0,2887 & 2,848 & 5,925 & 3,283 & 2,603 & 2,082 \\
\hline & 8 & Mean & 20 & 158 & 129,3 & 10,33 & 15,5 & 35 & 265,7 & 46,5 & 136 & 132,7 \\
\hline & & Std. Error & $\mathrm{I}, 155$ & 3,464 & 3,18 & I,764 & 1,443 & 2,309 & 11,98 & 0,866 & 6,245 & 5,487 \\
\hline & 9 & Mean & 20,67 & 160,7 & 118,3 & 4,333 & 8,333 & 33,5 & 233 & 59 & 129,3 & 130 \\
\hline & & Std. Error & 1,764 & 5,239 & 4,41 & 1,453 & $\mathrm{I}, 453$ & 0,866 & 7,506 & 2,887 & 5,783 & 3,215 \\
\hline & 10 & Mean & 13,33 & 105,3 & 65 & 14,67 & 2,667 & 15,5 & 107,7 & 25,33 & 59 & 62 \\
\hline & & Std. Error & 2,404 & 5,696 & 2,082 & $\mathrm{I}, 453$ & $\mathrm{I}, 202$ & 1,607 & 3,844 & 3,844 & 2,082 & 1,732 \\
\hline \multirow{20}{*}{$\begin{array}{c}\text { Patch test positive to Pd } \\
\text { (Group 2) }\end{array}$} & 11 & Mean & 10 & 69,33 & 11 & 45,33 & 2,333 & 27 & 197,3 & 84,33 & 21 & 129,3 \\
\hline & & Std. Error & $\mathrm{I}, 155$ & 3,48 & 0,5774 & 2,603 & 1,333 & 2,887 & 7,219 & 2,404 & 3,606 & 3,18 \\
\hline & 12 & Mean & 14,33 & 100,3 & 20,67 & 83,67 & 15,67 & 16,5 & 124,7 & 58,67 & 10,33 & 68,33 \\
\hline & & Std. Error & 3,844 & 1,453 & 2,333 & 4,631 & $\mathrm{I}, 202$ & $\mathrm{I}, 443$ & 3,283 & 1,202 & 2,603 & 2,906 \\
\hline & 13 & Mean & 13 & 92 & 19,33 & 62,33 & 14 & 37,67 & 285 & 143 & 38 & 186 \\
\hline & & Std. Error & 3,215 & 5,686 & 2,028 & 3,844 & I,528 & $\mathrm{I}, 453$ & 5,508 & 2,309 & I,732 & 3,464 \\
\hline & 14 & Mean & 13,5 & 101 & 17 & 71,67 & 10,67 & 35,5 & 285 & 127,7 & 30 & 151 \\
\hline & & Std. Error & 0,866 & 7,937 & 3,215 & 2,333 & 0,8819 & 0,2887 & 5,508 & 4,41 & $\mathrm{I}, 155$ & 1,528 \\
\hline & 15 & Mean & 45 & 360,3 & 41 & 229,7 & 36,33 & 9,333 & 73,67 & 37,67 & 10,67 & 41,33 \\
\hline & & Std. Error & 1,732 & 9,351 & 1,732 & 2,906 & 3,48 & $\mathrm{I}, 764$ & 2,728 & 1,202 & 1,764 & 1,856 \\
\hline & 16 & Mean & 6,5 & 53 & 5,667 & 34 & 2 & 12 & 92 & 47,33 & 13,67 & 45,33 \\
\hline & & Std. Error & $\mathrm{I}, 443$ & 2,082 & 1,202 & 1,155 & 1,528 & I,528 & 2 & 1,856 & I,764 & 1,764 \\
\hline & 17 & Mean & 15,67 & 117,3 & 9,667 & 72,67 & 6,333 & 23,33 & 190 & 84 & 22 & 93 \\
\hline & & Std. Error & 3,48 & 7,688 & 0,6667 & I,453 & 0,8819 & 2,848 & 2,082 & 2,082 & 2,309 & 1,155 \\
\hline & 18 & Mean & 6,667 & 52 & 5,333 & 32 & 2 & 28,67 & 198,3 & 110,3 & 24 & 112 \\
\hline & & Std. Error & 1,764 & 3,512 & 0,8819 & 2,082 & 1 & 1,856 & 10,4 & 9,171 & 1,155 & 7,371 \\
\hline & 19 & Mean & 32,67 & 273 & 36 & 170,3 & 13,33 & 10,33 & 70,33 & 34,33 & 9,667 & 44 \\
\hline & & Std. Error & 1,202 & 3,606 & 2,646 & 5,548 & $\mathrm{I}, 202$ & 0,8819 & 2,728 & 3,283 & 1,202 & 2,646 \\
\hline & 20 & Mean & 30,67 & 244 & 24,33 & 153,3 & 7 & 28,67 & 197,3 & 120,7 & 31,67 & 116 \\
\hline & & Std. Error & 1,202 & 4,509 & 2,028 & 2,848 & 1,528 & 2,404 & 2,333 & 8,95 & I,764 & 4,041 \\
\hline $\begin{array}{c}\text { Patch test positive to } \mathrm{Ni} \\
\text { and } \mathrm{Pd}\end{array}$ & 21 & Mean & 14 & 105,7 & 89,67 & 17,67 & 10,67 & 20,33 & 153,7 & 32,67 & 72,33 & 81 \\
\hline (Group 3) & & Std. Error & 2,646 & 8,293 & 6,692 & 2,404 & $\mathrm{I}, 764$ & 1,453 & 5,783 & 3,528 & 2,333 & 3,786 \\
\hline & 22 & Mean & 24,83 & 172 & 150 & 25 & 25 & 22 & 176 & 26,67 & 79,67 & 93,67 \\
\hline & & Std. Error & 2,048 & 3,786 & 3,464 & 2,082 & 2,887 & 5,568 & 6,658 & 3,283 & 2,333 & 2,603 \\
\hline & 23 & Mean & 26,67 & 203,7 & 157 & 37,33 & 14,67 & 38,67 & 292,3 & 66,67 & 148,7 & 152 \\
\hline & & Std. Error & 1,453 & 8,686 & 4,619 & 2,333 & $\mathrm{I}, 764$ & 2,186 & 5,783 & 1,856 & 4,055 & 3,606 \\
\hline & 24 & Mean & 31 & 247 & 186 & 30,67 & 18,33 & 23,67 & 186,3 & 21,33 & 94,67 & 119,3 \\
\hline & & Std. Error & $\mathrm{I}, 155$ & 2,309 & 3,464 & 1,453 & 2,028 & 4,702 & 7,623 & 3,528 & 4,41 & 1,856 \\
\hline & 25 & Mean & 25,67 & 197 & 157,7 & 22,33 & 18 & 37,33 & 285 & 49 & 145,7 & 143 \\
\hline & & Std. Error & $\mathrm{I}, 764$ & 4,041 & 1,856 & 2,028 & 2,309 & $\mathrm{I}, 453$ & 5,508 & 3,215 & 3,383 & 3,215 \\
\hline & 26 & Mean & 20 & 157,7 & 117 & 16 & 10 & 15,5 & 125,3 & 29,67 & 56 & 61,67 \\
\hline & & Std. Error & 1,155 & 3,18 & 2,082 & 1,155 & 2,517 & 0,2887 & 4,667 & 1,667 & 2,887 & 1,764 \\
\hline
\end{tabular}


Table 2: Individual values of spot forming cells for each experimental condition expressed as mean values and Standard Errors of triplicate wells. (Continued)

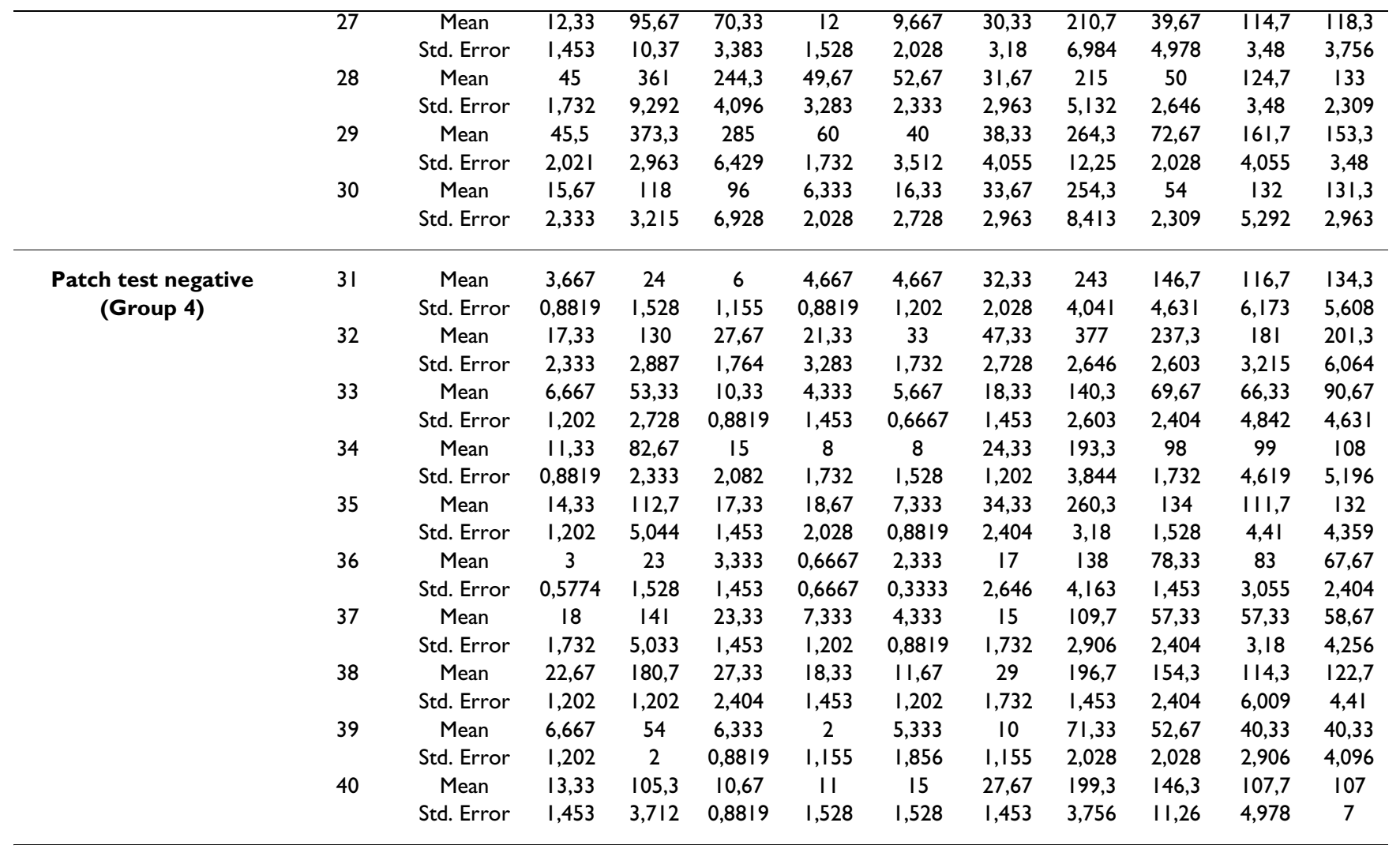

Patients were grouped following their patch test reactions. W/O: medium alone; PHA: polyclonal stimulation; Ni $20 \mu \mathrm{g} / \mathrm{ml}, \mathrm{Pd} 2.5 \mu \mathrm{g} / \mathrm{ml}, \mathrm{Rh} 5 \mu \mathrm{g} / \mathrm{ml}$.

of both subsets, and regulates the development of Th1 cells by blocking IL-12 driven Th1 responses [34]. IL-10 is thought to exert its effects by down-regulating the expression of co-stimulatory molecules required for appropriate antigen presentation [35]. Ferguson TA et al and Schwarz A et al $[36,37]$ demonstrated a key regulatory role for IL10 in both the induction and the effector phases of murine contact hypersensitivity. Our results provide evidence supporting the hypothesis that a regulatory mechanism mediated by IL-10 contributes to the control of hypersensitivity in response to $\mathrm{Ni}, \mathrm{Pd}$ and $\mathrm{Rh}$ therefore contrasting the development of ACD. Even if the protective role of IL-10 is well established, studies addressing the cytokine profile in subjects with or without ACD have been partly contradictory $[26,31,38]$. It should be considered that different protocols used for the in vitro stimulation or the different sensitivities of the immunoassays for IL-10 measurements could be responsible for the different results obtained.

The finding that not only Ni but also other metals could elicit a response in PBMC from sensitized subjects [15], was not surprising and prompted us to explore the profile of cytokine production in patients which scored negative at patch testing toward Pd and $\mathrm{Rh}$, which are present in several synthetic materials including new metallic alloys $[39,40]$. Remarkably, we found very clear-cut, divergent, IL-10 "protective" or IFN- $\gamma$ "reactive" profiles in patients showing a negative or positive skin reactivity to metal salts (group 1, 2, 4), respectively. Moreover, all the subjects with positive patch test to both $\mathrm{Ni}$ and Pd (group 3) showed an in vitro response similar to monosensitized patients to $\mathrm{Ni}$, characterized by the release of IFN- $\gamma$ after $\mathrm{Ni}$ stimulation and production of IL-10 in response to Pd or Rh. Interestingly, comparing the cytokine response to Pd, subjects with the same patch test reactivity $(\mathrm{n}=3:++$ in the group $2 ; \mathrm{n}=6:++$ in the group 3 ) displayed a reversed profile (Table 2). On the basis of these data, it is conceivable that a positive (IFN- $\gamma$ ) response in vitro may predict the development of adverse reaction to prosthesis alloys or to chemotherapeutic agents containing toxic metals. In fact, previous studies on multiple sensitivities to transition metals reported that the majority of $\mathrm{Ni} / \mathrm{Pd}$ reactions occurred without clinical evidence of Pd sensitization $[10,19,41]$.

We analyzed the IFN- $\gamma$ response in patients with an unambiguous Ni patch test reaction (group 1 and 3 patients with +++ reactions) to provide positive controls for the in vitro assay, in order to define optimal conditions for anti- 

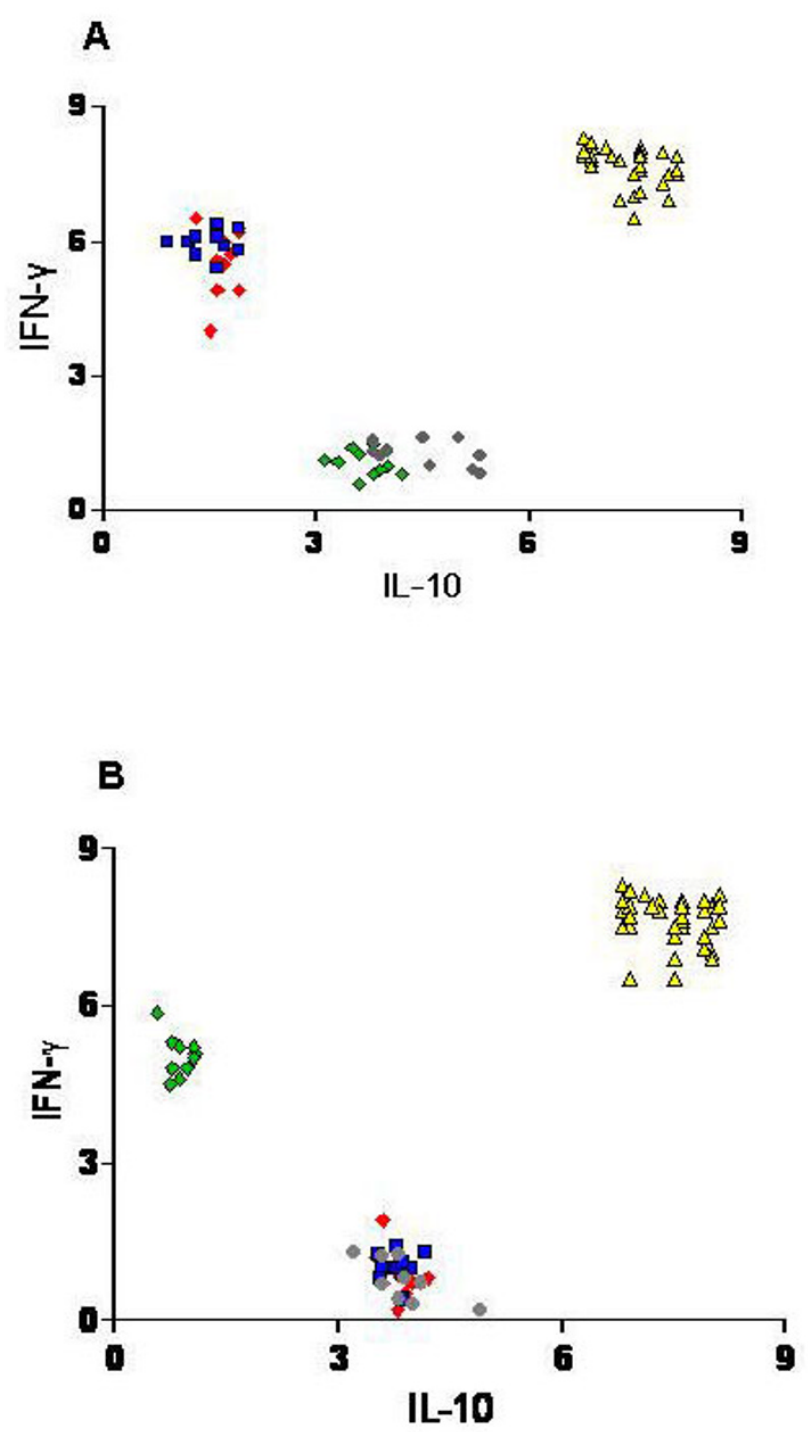

\section{Figure 2}

Scatter plot analysis of individual IFN- $\gamma$ and IL- 10 induction by PHA, Ni or Pd in the different group of patients. PHA induces PBMC release of both IFN- $\gamma$ and IL-10 in all subjects, while metal salts induces IFN- $\gamma$ or IL- 10 production according to the in vivo positive or negative response. IFN- $\gamma$ or IL- 10 production was alternatively produced and consequently a highly significant negative correlation was found (Spearman analysis P $<0.000$ I). Panel A: IFN- $\gamma$ and IL-I0 induction (Index) by PHA or $\mathrm{Ni}$ salt; B: IFN- $\gamma$ and IL-10 induction (Index) by PHA or Pd salt. Red Diamond: Group I (induced by Ni in panel A or by Pd in panel B), Green diamond: Group 2 (induced by Ni in panel A or by Pd in panel B), Blue square: Group 3 (induced by Ni in panel A or by Pd in panel B), Grey circle: Group 4 (induced by $\mathrm{Ni}$ in panel $\mathrm{A}$ or by $\mathrm{Pd}$ in panel B), Yellow triangle: Overall subjects (induced by PHA).

gen-specific cytokine production and to offer a highly sensitive and specific test suitable for clinical determinations. On the basis of this setting, stimulation values greater than 3 to 7 were commonly obtained with metal salts or with lectin (PHA) polyclonal stimulation, respectively, suggesting that cryopreservation did not affect the cytokine response of lymphocytes, as sustained by the study from Kreher et al [42].

The data gathered by the ELISpot analysis did not show any cross-reactivity of T-cells neither the co-existence of $\mathrm{T}$ cell clones with differential responsiveness. Since any Ni contamination was demonstrated in the Pd salt used for patch testing (data not shown), it is presumable that an immunologic cross-reactivity based on molecular mimicry among different hapten-carrier complexes might take place in vivo, at the skin level. Due to their small size, metal ions are incomplete antigens which have to bind to carrier molecules, which, in turn, are capable to capture metal ions, and shuttling this complex to the epidermal basement membrane $[4,7]$. On the other hand, the concomitant reactivity to $\mathrm{Ni}$ and $\mathrm{Pd}$, observed in a number of patients by skin testing could concern also the possibility of a delayed or impaired response of skin regulatory cells. A dysfunction in T-regulatory cell can lead to an immune activation often associated with the clinical expression of skin diseases such as atopic dermatitis and psoriasis [43]. Experimental data suggested also the possibility that, in analogy to superantigens, Ni or Pd may also directly link TCR and MHC in a peptide independent manner and can effectively amplify the hapten-specific immune response $[44,45]$. It is also known that a strong binding of different superantigens to the TCR could render T cells insensitive to suppression by CD4+CD25+ Treg cells [46] and IL-10 [47].

Knowledge about the immunologic mechanism responsible for ACD is still fragmentary. It is accepted that the sensitising chemical penetrates into the epidermis, and, depending on its properties, it "perturbates" the environment. However, neither the molecular nature of $\mathrm{Ni}$ induced antigenic determinants nor the very early molecular events of metal transport through the human epidermis to Langerhans cells have yet been satisfactorily resolved indicating that still many aspects of metal allergy remain unclear.

\section{Conclusion}

Taken together, these results demonstrate that different cytokine profiles elicited in vitro can reflect different immune responses in vivo in ACD. The development of sensitive and specific in vitro assays based on cytokine response could be extremely useful in complementing patch testing for the clinical diagnosis and characterization of metal sensitization.

\section{Methods \\ Patients}

Fourty patients $(\mathrm{n}=36$ female $(\mathrm{f}) / 4$ male $(\mathrm{m})$; mean age 33.3 yrs, range between 28-41) attending the Department of Allergy of this Institute were enrolled in the study. 
Patient assessment was primarily based on a detailed medical history, including history of metal exposure. Wearing of metal dental braces was also recorded. None of the patients had recently used immunosuppressive medication, underwent UV radiation or suffered from acute inflammatory skin diseases. The study received the approval from the Internal Ethic Committee of Istituti Fisioterapici Ospitalieri (San Gallicano, IFO, Rome), and an oral informed consent was obtained from all subjects prior to the in vitro study.

\section{Patch testing}

Patch testing was performed with all patients enrolled in the study. The skin patch tests were with the European standard series of contact allergens (Hermal Trolab, Reinbeck, Germany), including 5\% Nickel Sulphate hexahydrate $\left(\mathrm{NiSO}_{4} \times 6 \mathrm{H}_{2} \mathrm{O}\right)$ applied in petrolatum, and supplemented with $1 \%$ Palladium Chloride $\left(\mathrm{PdCl}_{2}\right)$ applied in petrolatum and 1\% Rhodium Acetate $\mathrm{Rh}\left(\mathrm{CH}_{3} \mathrm{COO}\right)_{2}$ in aqueous solution. These salts were from Merck (AG, Darmstadt, F.R.G). The patch tests were performed by applying Finn Chambers with haptens on unaffected skin of the upper backs of the subjects for $48 \mathrm{~h}$. Patch test responses were examined on day 2 and defined as strong (+++: oedema, erythema, papules and vesicles), moderate (++: oedema, erythema and papules), weak (+: oedema and erythema) or no reaction (-) according to the International Contact Dermatitis Research Group guidelines [48].

\section{ELISpot assay}

Peripheral blood mononuclear cells

PBMC were isolated from 5 to $10 \mathrm{ml}$ of heparinized blood, collected 48 hrs after skin testing, by standard Ficoll density-gradient centrifugation (Lympholyte- $\mathrm{H}$ solution Cederlane, Ontario, Canada) and washed twice with PBS. Cell aliquots were frozen in 90\% heat inactivated Fetal Bovine Serum (FBS, Euroclone) and 10\% DMSO (Dimethylsulphoxide, Sigma) and kept in liquid nitrogen until tested for ELISpot assay.

\section{Metal salts used for in vitro cytokine assay}

The metal salts used for in vitro assays were: nickel sulphate hexahydrate $\mathrm{NiSO}_{4} \times 6 \mathrm{H}_{2} \mathrm{O}$, palladium chloride $\left(\mathrm{PdCl}_{2}\right)$ and rhodium acetate $\mathrm{Rh}\left(\mathrm{CH}_{3} \mathrm{COO}\right)_{2}$ (Merck AG, Darmstadt, F.R.G). Before use, metals were resuspended in sterile saline solution at $2 \mathrm{mg} / \mathrm{ml}$ (Bioindustria, Novi Ligure, Italy). These stock solutions were found negative for LPS contamination (Limulus assay, BioWhittaker, Cambrex Company, USA).

\section{Definition of optimal metal salt concentrations for antigen-specific cytokine production}

Preliminary experiments were performed in order to determine the optimal concentration of each metal salt for IL-10 or IFN- $\gamma$ producing cells induction, measured by ELISpot assay. Briefly, $3.5 \times 10^{5} \mathrm{PBMC} /$ well from 5 nonallergic donors were stimulated with $10 \mu \mathrm{g} / \mathrm{ml}$ of phytohaemagglutinin (PHA, Sigma, Saint Louis, Missouri, USA) in the presence of different metal salts at concentrations ranging from $0.1 \mu \mathrm{g} / \mathrm{ml}$ to $100 \mu \mathrm{g} / \mathrm{ml}$. Metal salt concentrations $>50 \mu \mathrm{g} / \mathrm{ml},>25 \mu \mathrm{g} / \mathrm{ml}$ and $>30$ of Ni, Pd and $\mathrm{Rh}$ respectively inhibited the PHA-induced cytokine producing cells by $25 \%$, and were considered toxic in agreement with other authors (15). Subsequent preliminary experiments showed that $20 \mu \mathrm{g} / \mathrm{ml} \mathrm{NiSO}_{4}$ or $2.5 \mu \mathrm{g} / \mathrm{ml} \mathrm{PdCl}_{2}$ yielded the higher frequency of IFN- $\gamma$ producing cells in five subjects with clinical diagnosis of ACD caused by $\mathrm{Ni}$ $(n=3)$ or $\mathrm{Pd}(\mathrm{n}=2)$ respectively. While, PBMC from five healthy controls cultured at the same experimental conditions provided the higher frequency of IL-10 producing cells. Also the $\mathrm{Rh}\left(\mathrm{CH}_{3} \mathrm{COO}\right)_{2}$ concentration of $5 \mu \mathrm{g} / \mathrm{ml}$ was chosen on the basis of the higher frequency of IL-10 producing cells in patients as well as controls.

\section{Pre-incubation with metals}

For the detection of IFN- $\gamma$, PBMC $\left(3.5 \times 10^{5} /\right.$ well $)$ were pre-incubated with or without metals in round bottom polypropylene tubes (Becton Dickinson Labware) in complete medium (RPMI 1640, 10\% FBS, 1\% Penicillin-Streptomycin-L-Glutamine; GIBCO-BRL, UK) for $20 \mathrm{hrs}$ at $37^{\circ} \mathrm{C}$ and $5 \% \mathrm{CO}_{2}$ in humidified air. Then cells were transferred to the ELISpot plates and incubated for a further 48 hrs.

ELISpot assays were performed as previously described [49] with minor modifications. Briefly, Polyvinylidene difluoride-backed 96-well microtiter plates (MAIPS4510; Millipore Sunnyvale, CA, USA) were coated overnight at $4^{\circ} \mathrm{C}$ with $100 \mu \mathrm{l} /$ well of specific capture antibody antiIFN- $\gamma$ or anti-IL-10 (10 $\mu \mathrm{g} / \mathrm{ml}, 100 \mu \mathrm{l} /$ well, Endogen Woburn, MA) dissolved in phosphate buffered saline (PBS)

$\mathrm{Ab}$-coated plates were then washed three times and incubated $1 \mathrm{~h}$ at $37^{\circ} \mathrm{C}$ with complete medium to prevent nonspecific protein binding. PBMC were plated at $3.5 \times 10^{5} /$ well, to a final volume of $200 \mu \mathrm{l} /$ well of complete medium. Three different concentrations of $\mathrm{NiSO}_{4}$ (5-10$20 \mu \mathrm{g} / \mathrm{ml}), \mathrm{PdCl}_{2}$ and $\mathrm{Rh}\left(\mathrm{CH}_{3} \mathrm{COO}\right)_{2}(2.5-5-10 \mu \mathrm{g} / \mathrm{ml})$ were added in triplicate wells and plates were kept in a humidified atmosphere with $5 \% \mathrm{CO}_{2}$ at $37^{\circ} \mathrm{C}$. Control triplicate wells contained PBMC with medium alone or with phytohaemagglutinin (PHA $1 \mu \mathrm{g} / \mathrm{ml}$, Sigma, Saint Louis, Missouri, USA). After 48 hrs for IFN- $\gamma$ and 72 hrs for IL-10 detection, cells were lysed with ice-cold distilled water, and cells were removed by 4 rinses with PBS/0.05\% Tween $^{\circledR} 20$ (Sigma, St Louis, MO, USA). After a $90 \mathrm{~min}$ incubation with biotin labeled anti-IFN- $\gamma$ or anti-IL-10 detection antibodies $(1 \mu \mathrm{g} / \mathrm{ml}, 100 \mu \mathrm{l} /$ well, Endogen 
Woburn, MA), HRP-Streptavidin-alkaline phosphatase (Euroclone, PBS 1\% BSA) was added to the wells at a dilution of $1: 1000$ for $30 \mathrm{~min}$ at $37^{\circ} \mathrm{C}$ in the dark. Subsequent to specific substrate addition, the red spots were developed using AEC-chromogen solution (Sigma, St Louis, MO, USA) and analysed by the Automated ImmunoSpot Image Analyzer Software (AELVIS Tecnologies, TEMA ricerche, Italy). The results were expressed as the ratio (Index) between the number of spot forming cells detected upon stimulation and those present in the absence of stimuli. A positive response is defined by an Index $>3$.

\section{Statistical analysis}

The Mann-Whitney (MW) rank sum test was used to compare the cytokine responses between two different groups of patients. To evaluate the correlation between IFN- $\gamma$ and IL-10 producing cells, the Spearman rank coefficient $r$ was considered. A P value $<0.05$ was considered to be statistically significant. Statistical analysis was performed with GraphPad Software, version 4.00 (San Diego California USA).

\section{Authors' contributions}

VB: conceived of the study and participated in its design, carried out the ELISpot assays, drafted the manuscript. FP: carried out the patch tests and helped in the draft of the clinical section of the manuscript. PC-F: provided writing assistance and participated in the design and coordination of the study, performed the statistical analysis. AV: cryopreservation of PBMC from peripheral blood of patients enrolled in the study, carried out the Limulus assay on metal salts used for in vitro cytokine assay. AA: performed the statistical analysis and set the database with patients' clinical information. MP: carried out the patch tests, participated in the design of the study. FE: carried out the patch tests, provided writing assistance, participated in the design of the study. AC: carried out the patch tests, participated in the design of the study and participated in its coordination. All authors read and approved the final manuscript.

\section{References}

I. Everness KM, Gawkrodger DJ, Botham PA, Hunter JA: The discrimination between nickel-sensitive and non-nickel-sensitive subjects by an in vitro lymphocyte transformation test. $\mathrm{Br} J$ Dermatol 1990, I 22(3):293-8.

2. Girolomoni G, Sebastiani S, Albanesi C, Cavani A: T-cell subpopulations in the development of atopic and contact allergy. Curr Opin Immunol 200I, I3(6):733-7.

3. Summer B, Sander CA, Przybilla B, Thomas P: Molecular analysis of T-cell clonality with concomitant specific T-cell proliferation in vitro in nickel-allergic individuals. Allergy 200I, 56(8):767-70.

4. Thierse HJ, Moulon C, Allespach Y, Zimmermann B, Doetze A, Kuppig S, Wild D, Herberg F, Weltzien HU: Metal-protein complexmediated transport and delivery of $\mathrm{Ni2}+$ to $\mathrm{TCR} / \mathrm{MHC}$ contact sites in nickel-specific human $\mathbf{T}$ cell activation. J Immunol 2004, I72(3): 1926-34.
5. K Sadler PJ, Tucker A, Viles JH: Involvement of a lysine residue in the $\mathbf{N}$-terminal $\mathbf{N i 2}+$ and $\mathrm{Cu} 2+$ binding site of serum albumins. Comparison with $\mathrm{Co2}+, \mathbf{C d 2 +}$ and $\mathrm{Al} 3+$. Eur J Biochem 1994, 220(I):193-200.

6. Moulon C, Wild D, Dormoy A, Weltzien HU: MHC-dependent and -independent activation of human nickel-specific CD8+ cytotoxic T cells from allergic donors. J Invest Dermatol 1998, III(3):360-6.

7. Budinger L, Hertl M: Immunologic mechanisms in hypersensitivity reactions to metal ions: an overview. Allergy 2000, 55(2): 108-15.

8. Cavani A, Hackett CJ, Wilson KJ, Rothbard JB, Katz SI: Characterization of epitopes recognized by hapten-specific CD4+ T cells. J Immunol I995, I 54(3): I232-8.

9. Vamnes JS, Lygre GB, Gronningsaeter AG, Gjerdtet NR: Four years of clinical experience with an adverse reaction unit for dental biomaterials. Commun Dent Oral Epidemiol 2004, 32:150-7.

10. Cristaudo A, Sera F, Severino V, De Rocco M, Di Lella E, Picardo M: Occupational hypersensitivity to metal salts, including platinum, in the secondary industry. Allergy 2005, 60(2):159-64.

II. Gil FJ, Sanchez LA, Espias A, Planell JA: In vitro corrosion behaviour and metallic ion release of different prosthodontic alloys. Int Dent J 1999, 49(6):361-7.

12. Mahler DB, Engle JH, Adey JD: Effect of Pd on the clinical performance of amalgam. J Dent Res 1990, 69(I I): 1759-6I.

13. Boscolo P, Di Giampaolo L, Reale M, Castellani ML, Ritavolpe A, Carmignani M, Ponti J, Paganelli R, Sabbioni E, Conti P, Di Gioacchino M: Different effects of platinum, palladium, and rhodium salts on lymphocyte proliferation and cytokine release. Ann Clin Lab Sci 2004, 34(3):299-306.

14. Hegewald J, Uter W, Pfahlberg A, Geier J, Schnuch A: a multifactorial analysis of concurrent patch test reactions to nickel, cobalt, and chromate. Allergy 2005, 60:372-8.

15. Minang JT, Arestrom I, Troye-Blomberg M, Lundeberg L, Ahlborg N: Nickel, cobalt, chromium, palladium and gold induce a mixed ThI- and Th2-type cytokine response in vitro in subjects with contact allergy to the respective metals. Clin Exp Immunol 2006, I46(3):417-26.

16. Kielhorn J, Melber C, Keller D, Mangelsdorf I: Palladium: a review of exposure and effects to human health. Int J Hyg Environ Health 2002, 205(6):417-32.

17. Santucci B, Cristaudo A, Cannistraci C, Picardo M: Interaction of palladium ions with the skin. Exp Dermatol 1995, 4(4 Pt I):207-10.

18. Stingeni L, Brunelli L, Lisi P: Contact sensitivity to rhodium and iridium in consecutively patch tested subjects. Contact Dermatitis 2004, 51:5-6. 316-317.

19. Hindsen M, Spiren A, Bruze M: Cross-reactivity between nickel and palladium demonstrated by systemic administration of nickel. Contact Dermatitis 2005, 53(I):2-8.

20. Van Joost T, Roesyanto-Mahadi ID: Combined sensitization to palladium and nickel. Contact Dermatitis 1990, 22(4):227-8.

21. Basketter D, Dooms-Goossens A, Karlberg AT, Lepoittevin JP: The chemistry of contact allergy: why is a molecule allergenic? Contact Dermatitis 1995, 32(2):65-73.

22. Moulon C, Vollmer J, Weltzien HU: Characterization of processing requirements and metal cross-reactivities in $\mathrm{T}$ cell clones from patients with allergic contact dermatitis to nickel. Eur J Immunol 1995, 25(I 2):3308-I5.

23. Pistoor FH, Kapsenberg ML, Bos JD, Meinardi MM, von Blomberg ME, Scheper RJ: Cross-reactivity of human nickel-reactive T-lymphocyte clones with copper and palladium. J Invest Dermatol 1995, 105(I):92-5.

24. Sherertz EF, Fransway AF, Belsito DV, DeLeo VA, Fowler JF Jr, Maibach HI, Marks JG Jr, Mathias CG, Pratt MD, Rietschel RL, Taylor JS: Patch testing discordance alert: false-negative findings with rubber additives and fragrances. I Am Acad Dermatol 200I, 45(2):3।3-4.

25. Borg L, Christensen JM, Kristiansen J, Nielsen NH, Menne T, Poulsen LK: Nickel-induced cytokine production from mononuclear cells in nickel-sensitive individuals and controls. Cytokine profiles in nickel-sensitive individuals with nickel allergyrelated hand eczema before and after nickel challenge. Arch Dermatol Res 2000, 292(6):285-91.

26. Minang JT, Troye-Blomberg M, Lundeberg L, Ahlborg N: Nickel elicits concomitant and correlated in vitro production of ThI-, 
Th2-type and regulatory cytokines in subjects with contact allergy to nickel. Scand J Immunol 2005, 62(3):289-96.

27. Jakobson E, Masjedi K, Ahlborg N, Lundeberg L, Karlberg AT, Scheynius $A$ : Cytokine production in nickel-sensitized individuals analysed with enzyme-linked immunospot assay: possible implication for diagnosis. Br J Dermatol 2002, I47(3):442-9.

28. Lindemann M, Bohmer J, Zabel M, Grosse-Wilde H: ELISpot: a new tool for the detection of nickel sensitization. Clin Exp Allergy 2003, 33(7):992-8.

29. Traidl C, Sebastiani S, Albanesi C, Merk HF, Puddu P, Girolomoni G, Cavani A: Disparate cytotoxic activity of nickel-specific CD8+ and CD4+ T cell subsets against keratinocytes. J Immunol 2000, 165(6):3058-64.

30. Cavani A, Nasorri F, Prezzi C, Sebastiani S, Albanesi C, Girolomoni G: Human CD4+ $T$ lymphocytes with remarkable regulatory functions on dendritic cells and nickel-specific ThI immune responses. J Invest Dermatol 2000, I | 4(2):295-302.

31. Rustemeyer T, von Blomberg BM, van Hoogstraten IM, Bruynzeel DP, Scheper RJ: Analysis of effector and regulatory immune reactivity to nickel. Clin Exp Allergy 2004, 34(9): I 458-66.

32. Seidel-Guyenot W, Perschon S, Dechant N, Alt R, Knop J, Steinbrink $\mathrm{K}$ : Low zone tolerance induced by systemic application of allergens inhibits $\mathbf{T}(\mathbf{C}) \mathbf{I}$-mediated skin inflammation. J Allergy Clin Immunol 2006, I I 7(5): I I70-7.

33. Del Prete G, De Carli M, Almerigogna F, Giudizi MG, Biagiotti R, Romagnani S: Human IL- 10 is produced by both type I helper (ThI) and type 2 helper (Th2) T cell clones and inhibits their antigen-specific proliferation and cytokine production. J Immunol 1993, I50(2):353-60.

34. D'Andrea A, Aste-Amezaga M, Valiante NM, Ma X, Kubin M, Trinchieri G: Interleukin 10 (IL-10) inhibits human lymphocyte interferon gamma-production by suppressing natural killer cell stimulatory factor/IL- 12 synthesis in accessory cells. J Exp Med 1993, I 78(3): 104I-8.

35. De la Barrera S, Aleman M, Musella R, Schierloh P, Pasquinelli V, Garcia $V$, Abbate E, Sasiain Mdel C: IL- I 0 down-regulates costimulatory molecules on Mycobacterium tuberculosis-pulsed macrophages and impairs the lytic activity of CD4 and CD8 CTL in tuberculosis patients. Clin Exp Immunol 2004, I 38(I): | $28-38$.

36. Ferguson Ta, Dube P, Griffith Ts: Regulation of contact hypersensitivity by interleukin 10. J Exp Med 1994, 179:1597-1604.

37. Schwarz A, Grabbe S, Riemann H, Aragane $Y$, Simon M, Manon S, Andrade S, Luger TA, Zlotnik A, Schwarz T: In vivo effects of interleukin- 10 on contact hypersensitivity and delayed-type hypersensitivity reactions. J Invest Dermatol 1994, 103(2):2 I I-6.

38. Cederbrant K, Anderson C, Andersson T, Marcusson-Stahl M, Hultman P: Cytokine production, lymphocyte proliferation and Tcell receptor Vbeta expression in primary peripheral blood mononuclear cell cultures from nickel-allergic individuals. Int Arch Allergy Immunol 2003, I32(4):373-9.

39. De la Fuente EG, Alvarez JG, Vicente FJ, Sols M, Naz E, Lopez-Estebaranz JL: Occupational contact dermatitis caused by rhodium. Am J Contact Dermatol 2003, I4(3): 172-3.

40. Burgos AE, Belchior JC, Sinisterra RD: Controlled release of rhodium (II) carboxylates and their association complexes with cyclodextrins from hydroxyapatite matrix. Biomaterials 2002, 23(12):2519-26.

41. Santucci B, Cannistraci C, Cristaudo A, Picardo M: Multiple sensitivities to transition metals: the nickel palladium reactions. Contact Dermatitis 1996, 35(5):283-6.

42. Kreher CR, Dittrich MT, Guerkov R, Boehm BO, Tary-Lehmann M: CD4+ and CD8+ cells in cryopreserved human PBMC maintain full functionality in cytokine ELISPOT assays. J Immunol Methods 2003, 278(I-2):79-93.

43. Verhagen J, Akdis M, Traidl-Hoffmann C, Schmid-Grendelmeier P, Hijnen D, Knol EF, Behrendt H, Blaser K, Akdis CA: Absence of Tregulatory cell expression and function in atopic dermatitis skin. Allergy Clin Immunol 2006, I I 7( I): I76-83.

44. Nasorri F, Sebastiani S, Mariani V, De Pita O, Puddu P, Girolomoni G Cavani A: Activation of nickel-specific CD4+ T lymphocytes in the absence of professional antigen-presenting cells. J Invest Dermatol 2002, I I 8(I): I72-9.

45. Gamerdinger K, Moulon C, Karp DR, Van Bergen J, Koning F, Wild D, Pflugfelder $\mathrm{U}$, Weltzien $\mathrm{HU}$ : A new type of metal recognition by human $T$ cells: contact residues for peptide-independent bridging of $\mathbf{T}$ cell receptor and major histocompatibility complex by nickel. J Exp Med 2003, 197(10):1345-53.

46. Ou LS, Goleva E, Hall C, Leung DY: T regulatory cells in atopic dermatitis and subversion of their activity by superantigens. J Allergy Clin Immunol 2004, I I 3(4):756-63.

47. Joss A, Akdis M, Faith A, Blaser K, Akdis CA: IL-I 0 directly acts on T cells by specifically altering the CD28 co-stimulation pathway. Eur J Immunol 2000, 30(6): 1683-90.

48. Rietshel RL, Fowler JF Jr: Practical aspects of patch testing. In Fisher's Contact Dermatitis 5th edition. Edited by: Rietshel RL, Fowler JF Jr. Philadelphia: Lipincott Williams and Wilkins; 200I:9-26.

49. Bordignon V, Sinagra JL, Trento E, Pietravalle M, Capitanio B, Cordial Fei P: Antigen specific cytokine response in pediatric patients with atopic dermatitis. Pediatr Allergy Immunol 2005, I6(2): I I3-20.
Publish with Biomed Central and every scientist can read your work free of charge

"BioMed Central will be the most significant development for disseminating the results of biomedical research in our lifetime. "

Sir Paul Nurse, Cancer Research UK

Your research papers will be:

- available free of charge to the entire biomedical community

- peer reviewed and published immediately upon acceptance

- cited in PubMed and archived on PubMed Central

- yours - you keep the copyright

Submit your manuscript here:

http://www.biomedcentral.com/info/publishing_adv.asp
BioMedcentral 